\title{
Abdul-Akeem Sadiq* and Robert McCreight Assessing the Chemical Facility Anti-Terrorism Standards after 5 Years: Achievements, Challenges, and Risks Ahead
}

\begin{abstract}
Congress mandated the Department of Homeland Security to regulate chemical facilities with the goal of increasing security at these facilities to prevent future terrorist attacks. In 2007, DHS issued an interim rule known as the chemical facility anti-terrorism standards (CFATS). This paper takes a look at CFATS 5 years after implementation and discusses the achievements and the challenges confronting this important piece of legislation. In addition, this paper poses several questions and discusses some CFATS issues and concerns that have far-reaching implications for CFATS stakeholders, homeland security, and emergency management.
\end{abstract}

Keywords: CFATS; chemical security; infrastructure protection; risks; terrorism.

\footnotetext{
*Corresponding author: Abdul-Akeem Sadiq, School of Public and Environmental Affairs, Indiana University Purdue University Indianapolis, 801 West Michigan Street, BS 4070, Indianapolis, IN 46202, USA, Phone: +317 278-1013, Fax: +317 274-7860, e-mail: asadiq@iupui.edu Robert McCreight: Elliott School of International Affairs, George Washington University, 1957 E Street, NW, Washington, DC 20052, USA
}

\section{Introduction}

Hazardous chemicals, if released or misused, can pose significant threats to surrounding communities. ${ }^{1}$ Prior to the $9 / 11$ terrorist attacks, congressional policy makers had expressed concern about the safety and security of US chemical facilities containing hazardous chemicals, but they had not proactively implemented safety and security measures to safeguard these facilities. ${ }^{2}$ After the attacks, as awareness of future threats increased, chemical industry leaders - without any government intervention - began to proactively install security enhancements

1 George D. Haddow, Jane A. Bullock, and Damon P. Coppola, Introduction to Emergency Management (Burlington, MA: Elsevier, 2011).

2 Dana A. Shea, Chemical Facility Security: Issues and Options for the 112th Congress, CRS Report (Washington, DC: Congressional Research Service, December 21, 2012), 1, www.fas.org/sgp/crs/ homesec/R41642.pdf. 
at their facilities. ${ }^{3}$ Congress, having also become more aware of the possibility of chemical terrorist attacks, passed legislation in 2006 giving the department of homeland security (DHS) the mandate to regulate chemical facilities through the chemical facility anti-terrorism standards (CFATS) ${ }^{4}$ in order to increase security at chemical facilities. DHS gave the responsibility for overseeing CFATS to the infrastructure security compliance division (ISCD). ${ }^{5}$ ISCD is under the Office of infrastructure protection (IP), which itself is under DHS's national protection and program directorate (NPPD). Since 2006, Congress has extended the statutory authority of CFATS on an ad hoc basis. CFATS will expire on March 27, 2013, although President Obama has requested that Congress extend it until October 4, 2013. ${ }^{6}$ Different stakeholders - the chemical industry, DHS, advocacy groups, and policy makers - have also called for a reauthorization of CFATS. ${ }^{7}$

While the requested extension of CFATS is pending, it is reasonable to examine how the law and its implementing regulations have been operating thus far. This is especially important for at least six distinct reasons: (1) Does CFATS, as implemented, actually reflect the will of Congress? (2) Does CFATS, as implemented, actually ramp up security for the chemical industry? (3) Is the risk-based system used for CFATS vulnerability assessments a rational fit within the CFATS regulatory scheme? (4) Has CFATS, since its implementation, provided a balanced set of benefits to both the US government and the chemical industry? (5) What are the best arguments for and against an extension of CFATS? (6) Is CFATS, as implemented, leading to unintended consequences?

These six initial questions are very important for emergency management and homeland security purposes because the US chemical industry has to address the fact that major chemical facilities, which process, store, or produce highly toxic chemicals, can put their surrounding neighborhoods and employees into lethal jeopardy that may exceed the capabilities of local first responders to control. In addition, those chemical facilities highest in value and vulnerability are a major

3 William E. Allmond, “Testimony," The Chemical Facility Anti-Terrorism Standards Program: Addressing Its Challenges and Finding a Way Forward (testimony before the House Committee on Homeland Security, Subcommittee on Cybersecurity, Infrastructure Protection, and Security Technologies, 112th Cong., 2nd sess., March 6, 2012), 3, www.hsdl.org/?view\&did=703955.

4 Shea, Chemical Facility Security, p. 1.

5 Rand Beers, "Statement for the Record," Evaluating Internal Operation and Implementation of the chemical facility anti-terrorism standards program (CFATS) by the Department of Homeland Security (testimony before the House Committee on Energy and Commerce, Subcommittee on Environment and the Economy, 112th Cong., 2nd session, February 3, 2012), p. 2, energycommerce.house.gov/sites/republicans.energycommerce.house.gov/files/Hearings/EE/20120203/ HHRG-112-IF18-WState-RBeers-20120203.pdf; Shea, Chemical Facility Security, p. 4.

6 Shea, Chemical Facility Security, p. 1.

7 Ibid. 
critical infrastructure of the US and thus may require an enhanced level of both passive and active defenses.

To better assess CFATS after 5 years, this paper addresses those six questions in brief and presents an overview of the CFATS process and of how we arrived at this juncture in the extension of CFATS regulations. It then discusses CFATS issues and concerns with respect to the chemical industry, Congress, DHS, and public safety. Next, it reviews the major achievements, challenges, and the risks ahead. Finally, it speculates on the future of CFATS.

\section{Brief Overview of the CFATS Process}

According to an interim final rule issued by DHS on April 9, 2007, the secretary of DHS identified 322 "chemicals of interest" (COI) ${ }^{8}$ Chemical facilities are categorized according to the screening threshold of each chemical of interest they possess. ${ }^{9}$ DHS characterizes the potential risks that these COI can pose on the basis of three contexts: release, theft or diversion, and sabotage and contamination. ${ }^{10}$ It is important to note that DHS has issued interim CFATS regulations, which, apart from what the law calls for, have since 2007 provided the governing umbrella for the US chemical industry on key issues such as COI. It remains to be seen whether CFATS will be extended as an interim regulation, or whether changes in the language of the law will be made.

A chemical facility that contains any of the COI at the threshold quantities established by DHS has to submit a consequence-based screening tool, "TopScreen," to DHS, after which a preliminary risk tier will be assigned to the facility. ${ }^{11}$ DHS can assign a risk tier of 1-4, where tier 1 is designated for chemical facilities with the highest risk level. ${ }^{12}$ Once a risk tier is assigned, a facility has 90 days to submit a security vulnerability assessment (SVA). Thereafter DHS reviews the

\footnotetext{
8 Shea, Chemical Facility Security, p. 2.

9 Ibid.; Beers, "Statement for the Record, " p. 3; Government Accountability Office, Critical Infrastructure Protection: DHS Is Taking Action to Better Manage Its Chemical Security Program, but It Is Too Early to Assess Results,GAO-12-515T, Testimony before the House Committee on Appropriations, Subcommittee on Homeland Security (statement of Stephen L. Caldwell, director, Homeland Security and Justice, July 26, 2012), www.gao.gov/assets/600/593020.pdf.

10 Shea, Chemical Facility Security, p. 2.

11 Suzanne Spaulding, "Statement for the Record," Department Of Homeland Security - chemical facility anti-terrorism standards (CFATS) Program (testimony before the House Committee on Appropriations, Subcommittee on Homeland Security, 112th Congress, 2nd Session, July 26, 2012), p. 3, www.hsdl.org/?view\&did=719047.

12 Beers, "Statement for the Record," 3.
} 
SVA and assigns a final tier level. The facility then has 120 days in which to submit a site security plan (SSP) or an alternate security plan (ASP), and it can use the Chemical Security Assessment Tool developed by ISCD to conduct and develop its plan. ${ }^{13}$ Once the SSP/ASP is submitted, DHS reviews it, inspects the facility, and either approves the plan or disapproves it. If the plan is approved, the facility can implement it and is considered CFATS compliant.${ }^{14}$ If the plan is disapproved, the facility has to address the deficiencies identified during the inspection and resubmit the SSP/ASP (see Figure 1).

\section{Six Key Questions}

For various reasons, the aforementioned six questions have immediate implications for emergency management and homeland security. Briefly examining the answers to these questions while also reviewing other issues, this paper provides a better picture of what lies ahead as the public policy dimensions of a CFATS extension loom. There are many legitimate questions that could be raised to assess those dimensions of CFATS and of its impending extension, but a few fundamental issues should be confronted first.

The first thorny issue to be tackled involves the degree to which CFATS, as implemented thus far, actually reflects the will of Congress. Diverse opinions will emerge on this question, and interest groups of all stripes concerned about the extension of CFATS will weigh in before a formal extension decision is made. DHS will likely argue that its regulations parallel congressional intent, but will the chemical industry agree? Will public interest watchdog groups agree?

Second, who is in the best position to assess the degree to which CFATS, as implemented, has actually ramped up chemical facility security? The chemical industry itself? DHS and chemical experts? Academics, chemical industry leaders, and DHS in unison? Although this issue is crucial and as yet undefined, it appears that DHS, some chemical industry representatives, and some congressional members think that CFATS is making the industry safer..$^{15}$ If this is true, the next question is, how broad is that consensus among these key interest groups?

Third, is the risk-based system for CFATS, which relies on a uniform definition of COI, chemical-terrorism vulnerability information (CVI), or an SSP, a rational fit within the CFATS regulatory scheme? One haunting scenario holds

13 Ibid.

14 Ibid.

15 Allmond, "Testimony"; Beers, "Statement for the Record"; and Shea, Chemical Facility Security. 


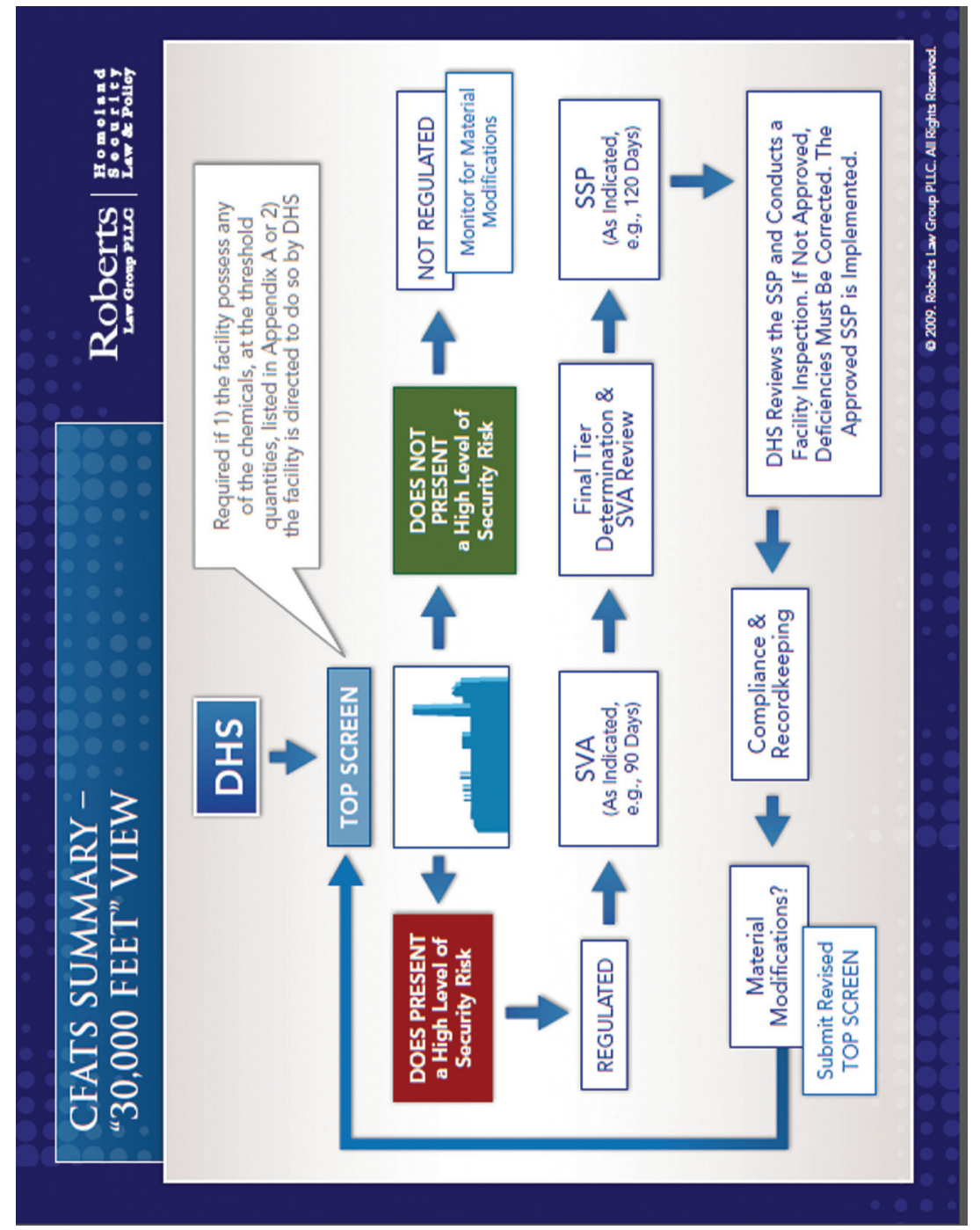

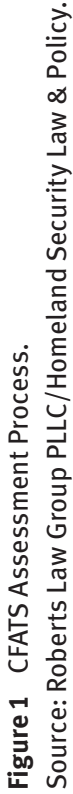


that there is an irreconcilable difference between these regulatory metrics, which turn principally on the myriad risk-management systems, and the solutions one could select that would arguably be most effective from both an industry and a homeland security standpoint. The degree to which certain risk-based systems are challenged or favored over others endorsed by DHS or the chemical industry or public interest groups is very uncertain.

A fourth issue entails the controversial matter of whether the existing interim regulations, whether continued or modified, actually balance real benefits for both the US government and the chemical industry. If the balance is tilted to favor one party over the other, is this good public policy? Balancing public safety and security interests against enterprise interests is always a dicey proposition, and it brings with it a host of unanswered questions about the inherent trade-offs involved. Questions about how the balance is to be achieved and how it will be structured are ambiguous at best.

A fifth issue is that only by looking back at the totality of CFATS interim regulations as implemented can one make an honest and objective assessment as to whether a CFATS extension is warranted. Certainly, political, economic, systems operations, and security questions must be factored into any such decision, but should we expect to see a rigorously neutral approach without extraneous and non-meritorious influences? What objective and rational criteria will guide the decision about CFATS continuation as is?

Finally, it is important to know whether CFATS is leading to unintended consequences, such as inadvertent compromises in public safety, reductions in chemical production, or chemical facilities relocating some or all of their processes overseas or going out of business altogether. If the answer is yes, a major implication would be a reduction in the number of chemical industry-related jobs available in the US.

\section{CFATS Issues and Concerns}

As we move through the assessment of CFATS, some key issues and concerns to four CFATS stakeholders - the chemical industry, Congress, DHS, and the public - should be considered. This is not an exhaustive list, but it illustrates the complexity of the undertaking. The issues discussed under each CFATS stakeholder below are those that are directly relevant to that stakeholder and may be indirectly relevant to other stakeholders. However, some issues that are directly relevant to multiple stakeholders are discussed under one stakeholder. For example, insufficient funding is both a congressional and DHS issue. 


\subsection{The Chemical Industry}

\subsubsection{Long-term Extension of CFATS}

Although the chemical industry has invested billions of dollars in security measures ${ }^{16}$ many chemical facilities are reluctant to invest more in security measures because CFATS has not been permanently authorized. The industry is in limbo on what security measures to put in place in case the CFATS program is not given permanent authorization or goes away all together. According to a recent study by the American chemistry council (ACC), the industry thinks an extension of CFATS will improve security at chemical facilities. ${ }^{17}$ Although DHS has shown support for the permanent authorization of CFATS,${ }^{18}$ there is no indication that Congress will approve such an authorization. The implication of a lack of long-term extension can be summed up by the statement of Matthew Leary, the corporate environmental health and safety manager for Pilot Chemical Company during his testimony before the House Committee on Energy and Commerce's Subcommittee on Environment and the Economy: "we cannot spend dollars on security in advance unless we are clear that what is spent will directly lead to compliance with the [CFATS] standard." ${ }^{19}$

\subsubsection{Transparency of CFATS}

One issue of transparency is that tier assignment is a black box to the chemical industry. No one in the industry seems to understand how facilities are assigned tiers - perhaps because the information on which tier assignments are based, including but not limited to information about chemical facility vulnerabilities, is not divulged to the public and is in fact protected by law. ${ }^{20}$ This may sound like a good idea in that sensitive information will not get into the hands of terrorists, but there are concerns about inability of local emergency management officials and first responders to access CVI. ${ }^{21}$ For instance, if there is a fire at a

16 Allmond, "Testimony."

17 Beers, "Statement for the Record," p. 9.

18 Ibid.

19 Matthew J. Leary, “Testimony," The Chemical Facility Anti-Terrorism Standards Program - A Progress Report (testimony before the House Committee on Energy and Commerce, Subcommittee on Environment and the Economy, 112th Cong., 2nd sess., September 11, 2012), p. 5, www. hsdl.org/?view\&did=722420.

20 Shea, Chemical Facility Security, pp. 16-17.

21 Ibid. 
chemical facility, firefighters must know what type of chemicals they are dealing with before they can try to put out the fire. This lack of transparency could cause covered facilities to mistrust the CFATS program and could lead to an increase in noncompliance.

There is also the central question of what compliance actually means. Is compliance uniformly applied to all tier 1 facilities, or does it vary with inspection regimes or contain internal variations among facilities to allow for distinctions between different plants and their production environments and chemical processes? Is there such a thing as "marginal compliance" or "marginal noncompliance," and what recourse does the chemical industry or DHS have to resolve technically ambiguous situations?

\subsection{Congress}

\subsubsection{Whether to Apply CFATS to Water and Wastewater Treatment Facilities}

Under the current provision, water and wastewater treatment facilities are exempt from CFATS. Because the federal government does not regulate these facilities although the owners can voluntarily engage in chemical security measures some advocacy groups, DHS, and the environmental protection agency (EPA) have called for the regulation of water and wastewater treatment facilities. ${ }^{22}$ The argument is that these facilities also have some COI that could harm communities if they fall into the wrong hands. Others have argued against this move, citing an adverse impact on the public (e.g., water may not be available to residents if the federal government shuts down the community's only water facility as a result of noncompliance) as a reason not to regulate water and wastewater treatment facilities. $^{23}$

\subsubsection{Whether CFATS Should Mandate the Chemical Industry to Incorporate Inherently Safer Technology}

Another lingering controversial issue is whether CFATS should mandate the chemical industry to incorporate inherently safer technologies (IST). Some chemical safety experts believe that the requirement of IST might make chemical

22 Shea, Chemical Facility Security, p. 18.

23 Shea, Chemical Facility Security, pp. 18-19. 
industries ship their operations overseas ${ }^{24}$ and that ISCD does not have the expertise to understand and implement IST. ${ }^{25}$

Still, we cannot judge the influential perspectives of the parties most passionate about CFATS extension unless we include the perspective of DHS.

\subsection{Department of Homeland Security}

\subsubsection{Personnel Surety}

A very important problem for ISCD is how to resolve the personnel surety requirement of CFATS. Risk-based performance standard (RBPS) \#12 "requires covered chemical facilities to verify and validate identity, check criminal history, verify and validate legal authorization to work, and identify individuals with terrorist ties." ${ }^{26}$ Although this RBPS makes sense, the chemical industry cannot implement the last requirement without the help of the Federal Bureau of Investigation, ${ }^{27}$ which is in charge of the Terrorist Screening Database. As a way forward, the society of chemical manufacturers and affiliates (SOCMA) has recommended that DHS leverage the use of existing federal credentials that already screen workers, such as the Transportation Worker Identification Credential. ${ }^{28}$ In so doing, ISCD would avoid duplication of effort. ${ }^{29}$

\subsubsection{Turnover in ISCD Management}

In the last few years, there have been several turnovers in ISCD leadership. The high turnover rate will slow down the progress of CFATS; this is because it takes time for new leadership to understand CFATS and build trust with the various stakeholders, including staff and the industry. In addition, continuous changes in leadership might send the wrong signal to stakeholders about the stability and consistency of CFATS regulation. As a result, the chemical industry may be reluctant to make additional investments in chemical security.

24 Leary, "Testimony."

25 Allmond, Chemical Facility Anti-Terrorism Standards Program, p. 8.

26 Department of Homeland Security [DHS] Appropriations Bill, 2013, H.R. 112-492, 112th Congress, 2nd session (2012), 103, www.gpo.gov/fdsys/pkg/CRPT-112hrpt492/pdf/CRPT-112hrpt492.pdf. 27 Leary, "Testimony."

28 Allmond, “Testimony,” p. 7.

29 DHS Appropriations Bill, 2013. 


\subsubsection{CFATS Inspection Rate}

Although the rate of inspections of chemical facilities is slow, two facilities have completed the CFATS process, and DHS has carried out nineteen authorization inspections as of September 2012. ${ }^{30}$ DHS anticipates that it will take about an additional 7 years to approve and complete the inspections for all covered facilities, ${ }^{31}$ despite the establishment of an Inspector Tools Working Group, which is supposed to help speed up inspections. ${ }^{32}$ The inspection regime itself, its technical integrity, and its uniformity of approach among facilities are as subject to internal and external scrutiny as any other aspect of CFATS. Would the DHS inspector general reserve the option of reviewing completed inspections to render an opinion on their operation?

Finally, we must be able to assess what some of the major public safety issues and concerns about a CFATS extension might be. Here is one worth noting.

\subsection{A Public Safety Concern: Use of Contractors to Perform Government Work}

One of the challenges mentioned in a November 2011 internal memo is the use of outside contractors to do government work. ${ }^{33}$ This practice can create a loophole in the chemical security system that could be exploited by terrorists: terrorists could conceivably set up a phony contracting business and bid for government contracts in order to gain access to sensitive information or restricted areas. Should this occur, they may be able to pose a significant threat to public safety. Aside from the potential threat to security, the use of contractors can be costly, lead to high turnover, constant training of new contractors, and loss of institutional knowledge. ${ }^{34}$

\section{Achievements of CFATS}

This section examines the achievements of CFATS during its short time in existence.

30 Shea, Chemical Facility Security, p. 13.

31 Ibid., pp. 13-14.

32 Spaulding, "Statement for the Record."

33 Shea, Chemical Facility Security, p. 10.

34 Allmond, “Testimony," p. 9. 


\subsection{Improved Safety of the Chemical Industry}

DHS officials believe that CFATS is making the chemical industry safer against potential terrorist attacks, ${ }^{35}$ and they not alone in this respect. Rep. John Shimkus, chairman of the Subcommittee on Environment and the Economy and SOCMA, also believes that CFATS is enhancing chemical security. ${ }^{36}$ In addition, a recent ACC study found that the chemical industry has made substantial investment in security measures since the passage of CFATS. ${ }^{37}$ Furthermore, since the start of CFATS, the total number of chemical facilities assigned to a risk tier has declined. ${ }^{38}$ According to NPPD deputy undersecretary Suzanne Spaulding, since CFATS was implemented, more than 1800 chemical facilities have completely removed their COI and more than 900 others have reduced their COI holdings and are no longer considered high risk. ${ }^{39}$ While there are many factors that may have contributed to this decline - for example, erroneous filings, process changes, and business operation decisions - DHS claims that CFATS is improving industry safety by inducing voluntary reductions in COI. ${ }^{40}$ In sum, it does appear that there is tripartite agreement among Congress, DHS, and the chemical industry that CFATS is making the chemical industry safer against potential terrorist attacks.

\subsection{Collaborations with Industry}

Although the level of collaboration between DHS and the chemical industry is not as high as the industry or Congress would like, it is fair to give credit to DHS for collaborating with the industry on some issues. A good example of this collaboration is the use of an alternate security plan (ASP) that was developed by ACC. DHS allows chemical facilities to use an ASP in lieu of an SSP, and the chemical industry seems happy to explore the use of an ASP.41 Although ACC plans to pilot the ASP template soon, it appears that the flexibility the ASP will give to chemical facilities will help to improve CFATS and increase chemical industry support for it.

DHS is also looking to collaborate with the chemical industry on other industry-led initiatives, such as SOCMA's ChemStewards ${ }^{\circledR}$ and ACC's Responsible

35 Beers, "Statement for the Record," p. 5.

36 Allmond, "Testimony”; Shea, Chemical Facility Security.

37 Beers, "Statement for the Record," p. 9.

38 Shea, Chemical Facility Security, p. 7.

39 Spaulding, "Statement for the Record," p. 1.

40 Shea, Chemical Facility Security, p. 7.

41 Spaulding, "Statement for the Record." 
Care $^{\circledR}{ }^{42}$ However, it is fair to question whether the extent of collaboration on the overall extension of CFATS is sufficient to enable its continuation without major changes.

\subsection{Training of CFATS Inspectors}

When Congress mandated DHS to implement CFATS in 2006, the department had no chemical facility security office or inspectors. ${ }^{43}$ However, since then, DHS has established an office of chemical facility security and has increased the number of inspectors. Further, it has implemented a Basic Inspector School training program. ${ }^{44}$ By February 2012, DHS had filled all fourteen available leadership positions and hired 102 inspectors out of 108 available positions..$^{45}$ These investments in personnel will go a long way toward making CFATS a better program.

\section{Challenges Facing CFATS}

We now examine some of the challenges facing CFATS, which are likely to influence the congressional decision on whether to extend the interim CFATS regulations. We also look at the cascading effects that these challenges may have on both the chemical industry and government.

\subsection{Little Progress}

One thing on which many stakeholders concur is that DHS has made a modicum of progress in implementing CFATS. The DHS Appropriations Bill, 2013 states that "in spite of ample appropriations provided by Congress, the Department has made little progress carrying out its regulatory responsibilities for ... the chemical facility anti-terrorism standards (CFATS) program." ${ }^{46}$ A report that came out of the internal review of ISCD and submitted to Undersecretary Beers in November 2011 notes that one of the challenges facing CFATS is ISCD's inability to review SSPs in a consistent and timely manner. ${ }^{47}$ In fact, at the time of

\footnotetext{
42 Ibid., p. 6.

43 Shea, Chemical Facility Security, p. 4.

44 Ibid.

45 Ibid.

46 DHS Appropriations Bill, 2013, p. 101.

47 Beers, "Statement for the Record."
} 
this report, 4200 SSPs submitted to DHS by chemical facilities had not been approved. ${ }^{48}$ This same report enumerates several reasons for the lack of progress: inability of DHS to conduct compliance inspections, lack of adequate record keeping, human resource issues, and the use of contractors to do government work, to mention a few. ${ }^{49}$ Two additional factors contributing to slow implementation of CFATS are inadequate funding and the lag between training of inspectors and their deployment into the field..$^{50}$ According to Allmond, the slow implementation of CFATS can lead to (1) uncertainty and, consequently, unwillingness of the chemical industry to invest in more security measures; (2) negative stories in the press, which would not augur well for DHS and CFATS; and (3) the chemical industry's belief that the federal government is not serious about chemical security. ${ }^{51}$

\subsection{Insufficient Funding for CFATS}

To implement CFATS, DHS needs adequate funding to hire and train staff and inspectors. Funds are also needed for providing the necessary tools such as vehicles for inspectors to carry out their jobs. Congress is unsure whether the funding given to DHS for CFATS implementation is adequate and whether prior funds were used appropriately. ${ }^{52}$ The answer to the former question is that more funding is needed to implement CFATS if the president's budget for fiscal year 2013 is anything to go by. According to this budget, the president has requested $\$ 74.544$ million for the ISC program, and part of this appropriation will be used to hire 253 full-time positions. ${ }^{53}$ With regard to the latter question, the ISCD internal report revealed that funds were squandered in the past (e.g., by hiring workers with insufficient skills and not keeping proper records of consumables used). ${ }^{54}$

48 Shea, Chemical Facility Security, p. 10.

49 Ibid.

50 Shea, Chemical Facility Security, p. 10.

51 Allmond, Chemical Facility Anti-Terrorism Standards Program, p. 6.

52 Shea, Chemical Facility Security, p. 12.

53 Rand Beers and David Wulf, "Statement for the Record," The Chemical Facility Anti-Terrorism Standards Program - A Progress Report (testimony before the House Committee on Energy and Commerce, Subcommittee on Environment and the Economy, 112th Congress, 2nd session, September 11, 2012), 7, www.hsdl.org/?view\&did=722420; Spaulding, “Statement for the Record," p. 7. 54 Shea, Chemical Facility Security, pp. 10-11. 


\subsection{Organizational Culture and Employee Morale}

Another challenge identified by the report on ISCD internal review has to do with the organizational culture and the employee morale..$^{55}$ The frequent change in ISCD leadership since the inception of CFATS has led to poor organizational structure and a lack of morale among ISCD employees. In addition, some ISCD employees had particular skills that did not fit well with what they were hired to do. ${ }^{56}$ For example, some inspectors only had prior law enforcement training. ${ }^{57}$ While law enforcement training is good for CFATS inspectors, knowledge of chemical processes is equally important. This shows that some employees simply did not have the necessary qualifications or training to get the job done. All these problems may lead to reduced productivity, low employee morale, and high turnover among ISCD employees.

\subsection{A Lack of Support from the Office of Infrastructure Protection and the National Program and Protection Directorate}

According to the report on ISCD internal review, the Office of infrastructure protection (IP) and the national program and protection directorate (NPPD) did not give the necessary support to ISCD to manage CFATS in the early days of the program. A lack of support from upper-level management has been shown to be a negative factor in adopting risk-reducing measures $;{ }^{58}$ it can also slow down the implementation of programs. In the case of CFATS, both IP and NPPD have to approve the CFATS provisions suggested by ISCD, give backing to the provisions, and provide funding to implement them. Without the full support of these two important bodies, it is practically impossible for the CFATS program to make headway.

\subsection{Anomaly in a DHS Risk-Assessment Tool}

An anomaly that was first discovered in one of the risk-assessment tools that DHS used to assign tiers to facilities was thought to have been resolved in May 2010. ${ }^{59}$ It

55 Beers, "Statement for the Record."

56 Ibid.

57 Mike Levine, "EXCLUSIVE: Beset by Strife at Chemical Security Office, DHS Internal Report Claims Anti-Terrorism Program Now in Jeopardy,” Foxnews, December 21, 2011, www.foxnews. com/politics/2011/12/21/exclusive-beset-by-strife-at-dhs-office-future-anti-terrorism-programnow-in/ (accessed February 23, 2013).

58 Abdul-Akeem Sadiq and Christopher Weible, "Obstacles and Disaster Risk Reduction: Survey of Memphis Organizations,” Natural Hazards Review 11, no. 3 (2010), pp. 110-117.

59 Shea, Chemical Facility Security, p. 6. 
was only in June 2011, when a new acting ISCD director came into office, that this anomaly was "rediscovered" and rectified, resulting in the reassignment of about 500 facilities to a lower-risk tier. ${ }^{60}$ This anomaly in DHS's risk-assessment tool can lead the chemical industry to mistrust the risk tier process and, as a result, can jeopardize the progress of the CFATS program.

\section{The Future of CFATS}

Best- versus worst-case scenarios are often hard to identify when so many intervening variables are involved. In a grossly analytical manner, it is possible to briefly outline a series of possibilities with regard to the future of CFATS interim federal regulations (IFR): (1) they are extended without changes; (2) they are extended with minor changes; (3) they are extended but with major changes/ enhancements; or (4) they are not extended. The future of the IFR is not easy to predict. Questions about who benefits and who is disadvantaged get lost somehow in the traditional tug-of-war between what is good public policy as an independent outcome per se versus whatever is good for the industry versus DHS. On the one hand, if the industry feels that the IFR have been oppressive and curtail efficient operations, political and economic pressures may call for their nullification or major modification. On the other hand, if the IFR are deemed to be "in the public interest" by solidifying DHS leadership in this domain through extension or strengthening of the regulations, another outcome is likely.

\section{Risks that Will Not Go Away}

It is possible that the list of covered facilities will grow in the future as more facilities engage in chemical processes involving one or more COI, or as currently covered facilities become riskier or climb up in the risk-tier ladder. The current number of covered facilities and the potential for that number to increase could heighten our vulnerability to potential chemical terrorist attacks in the future, which would present an even more daunting homeland security and emergency management problem. For instance, toxic clouds of lethal chemicals could present a threat so widespread and persistent that no assembly of local firefighters augmented by military units could suppress the ensuing death and destruction.

60 Ibid. 


\section{Conclusion}

A major realization after the 9/11 terrorist attacks was, and continues to be, that our chemical facilities and infrastructure could be targeted by terrorists. As a result, Congress gave DHS the mandate to regulate chemical facilities. DHS's implementation of CFATS 5 years ago has very important implications for homeland security and emergency management. Hence, it is necessary to assess CFATS since its implementation by focusing on its achievements, its challenges, and the risks that the chemical industry poses to circumjacent communities. This paper has discussed several issues that are relevant to four key CFATS stakeholders: the chemical industry, Congress, DHS, and the public. These issues include transparency of CFATS, whether to apply CFATS to water and wastewater treatment facilities, the inspection rate of CFATS, and the use of contractors to perform government work, respectively.

It is important to note that since the implementation of CFATS, this burgeoning program has made some notable achievements, such as making the chemical industry safer. However, CFATS has some challenges as well, such as insufficient funding. These achievements and challenges will have a tremendous impact on Congress's decision on whether to continue or discontinue the program. While it is unclear what Congress will do, what is clear is that presumptive measures for ensure physical security and protection from sabotage, insider threats, theft and diversion, and toxic releases by terrorists cannot be established to handle all possible crisis scenarios, whether those scenarios are triggered by a terrorist attack or a major earthquake. A collaborative partnership must exist, which brings the chemical industry, DHS, the military, health officials, local emergency managers, and the public together to assess - using tabletop and formal exercises - the extent to which risks can be mitigated or controlled. Without such collaboration, it will be very difficult to establish presumptive measures to thwart terrorist attacks against chemical facilities.

The issues we have raised here are not exhaustive, but they should serve as a starting place for researchers interested in exploring CFATS and downstream chemical security-related issues. The chemical industry is part of our nation's critical infrastructure, and its products are essential to our economy and national defense. Hence, its ability to move forward in chemical production and innovation while balancing public safety and security is crucial. We therefore call for further research in this area with the hope of improving chemical security and preventing future terrorist attacks against our critical infrastructure. 


\section{References}

Allmond, William E. "Testimony." The Chemical Facility Anti-Terrorism Standards Program: Addressing Its Challenges \& Finding a Way Forward. Testimony before the House Committee on Homeland Security, Subcommittee on Cybersecurity, Infrastructure Protection, and Security Technologies, 112th Cong., 2nd sess., March 6, 2012. http://www. gpo.gov/fdsys/pkg/CHRG-112hhrg76601/html/CHRG-112hhrg76601.htm.

Beers, Rand. "Statement for the Record." Evaluating Internal Operation and Implementation of the Chemical Facility Anti-Terrorism Standards Program (CFATS) by the Department of Homeland Security. Testimony before the House Subcommittee on Environment and the Economy, Committee on Energy and Commerce, 112th Cong., 2nd sess., February 3, 2012. energycommerce.house.gov/sites/republicans.energycommerce.house.gov/files/ Hearings/EE/20120203/HHRG-112-IF18-WState-RBeers-20120203.pdf.

Beers, Rand and David Wulf. "Statement for the Record." The Chemical Facility Anti-Terrorism Standards Program-A Progress Report. Testimony before the House Committee on Energy and Commerce, Subcommittee on Environment and the Economy, 112th Congress, 2nd Session September 11, 2012. www.hsdl.org/?view\&did=722420.

Government Accountability Office. Critical Infrastructure Protection: DHS Is Taking Action to Better Manage Its Chemical Security Program, but It Is Too Early to Assess Results, GAO-12-515T. Testimony before the Subcommittee on Homeland Security, Committee on Appropriations, House of Representatives. Statement of Stephen L. Caldwell, director, Homeland Security and Justice, July 26, 2012. www.gao.gov/assets/600/593020.pdf.

Haddow, George D., Jane A. Bullock and Damon P. Coppola (2011) Introduction to Emergency Management. Burlington, MA: Elsevier.

House of Representatives. Department of Homeland Security Appropriations Bill, 2013. H.R. 112-492. 112th Congress, 2nd Session, (2012), 101-105. http://www.gpo.gov/fdsys/pkg/ CRPT-112hrpt492/pdf/CRPT-112hrpt492.pdf.

Leary, Matthew J. The Chemical Facility Anti-Terrorism Standards Program-A Progress Report. Testimony before the House Committee on Energy and Commerce, Subcommittee on Environment and the Economy, 112th Congress, 2nd Session, September 11, 2012. http:// energycommerce.house.gov/sites/republicans.energycommerce.house.gov/files/ Hearings/EE/20120911/HHRG-112-IF18-WState-LearyM-20120912.pdf.

Levine, Mike. "Beset by Strife at Chemical Security Office, DHS Internal Report Claims Anti-Terrorism Program Now in Jeopardy." Foxnews, December 21, 2011. http://www. foxnews.com/politics/2011/12/21/exclusive-beset-by-strife-at-dhs-office-future-antiterrorism-program-now-in/. Accessed February 23, 2013.

Sadiq, Abdul-Akeem and Christopher Weible (2010) "Obstacles and Disaster Risk Reduction: Survey of Memphis Organizations," Natural Hazards Review, 11(3):110-117.

Shea, Dana A. Chemical Facility Security: Issues and Options for the 112th Congress. CRS Report. Washington, DC: Congressional Research Service, October 2, 2012. http://www. fas.org/sgp/crs/homesec/R41642.pdf\#search=Counterterrorism.

Spaulding, Suzanne. "Statement for the Record." Department of Homeland Security-Chemical Facility Anti-Terrorism Standards (CFATS) Program. Testimony before the House Committee on Appropriations, Subcommittee on Homeland Security, 112th Congress, 2nd Session, July 26, 2012. www.hsdl.org/?view\&did=719047. 
Dr. Abdul-Akeem Sadiq is an Assistant Professor at the School of Public and Environmental Affairs at Indiana University Purdue University Indianapolis. He teaches undergraduate and graduate courses in emergency management, public safety management, and terrorism.

Dr. Robert McCreight is an Adjunct Professor in the Elliott School of International Affairs at George Washington University. He has published several articles on homeland security and National defense. 